\title{
ANALISIS KESULITAN SISWA DALAM MENYELESAIKAN SOAL CERITA OPERASI HITUNG PADA BILANGAN PECAHAN CAMPURAN
}

\author{
Errina Ida Zalima ${ }^{1}$, Ferdianus Panggar Njanji², Lasmiatik ${ }^{3}$, Leni Agustina ${ }^{4}$, \\ Maria Dela5, Mika Ambarawati6 \\ 1,23,4,5 Pendidikan Matematika IKIP Budi Utomo Malang
}
zalimaerrina@gmail.com¹, njanjianadesa@gmail.com², lasmiatikoppo@gmail.com³, lenia7154@gmail.com4 ${ }^{4}$ mariadela544@gmail.com5 ${ }^{5}$, mikaambarawatio88@gmail.com ${ }^{6}$

\begin{abstract}
Abstrak
Penelitian ini mendeskripsikan kesulitan siswa dalam menyelesaikan soal cerita operasi hitung pada bilangan pecahan campuran kelas VI MI Darussalam Malang. Jenis penelitian ini adalah penelitian deskriptif dengan pendekatan kualitatif. Subjek penelitian adalah siswa kelas VI MI Darussalam Malang dengan kategori nilai tinggi, sedang, dan rendah. Hasil penelitian menunjukkan bahwa: (1) siswa dengan kategori nilai tinggi dan sedang tidak mengalami kesulitan dalam mengubah pecahan campuran ke pecahan biasa, tetapi siswa dengan kategori nilai rendah mengalami kesulitan dalam mengubah pecahan campuran ke pecahan biasa; (2) siswa dengan kategori nilai tinggi tidak mengalami kesulitan menyamakan penyebut, tetapi siswa dengan kategori nilai sedang dan rendah mengalami kesulitan dalam menyamakan penyebut bilangan pecahan; (3) siswa dengan ketiga kategori nilai tinggi, sedang, dan rendah mengalami kesulitan dalam operasi hitung bilangan pecahan dengan tiga bilangan campuran; dan (4) siswa dengan kategori nilai tinggi, sedang, dan rendah mengalami kesulitan dalam menyelesaikan operasi hitung bilangan pecahan campuran.
\end{abstract}

Kata kunci: analisis kesulitan, soal cerita, operasi hitung, bilangan pecahan campuran

\begin{abstract}
This study describe the analysis of the difficulty of students in completing problem arithmetic operations on mixed numbers class VI MI Darussalam Malang. This type of research is a descriptive study with a qualitative approach. The subjects of this study are students of class VI MI Darussalam Malang with high, medium, and low grades. The results showed that: (1) students in the high and medium grades did not have difficulty in changing mixed fractions to ordinary fractions, however students in the low grade category have difficulty in converting mixed fractions to ordinary fractions; (2) students in the high grade category have no difficulty equating the denominator, however students in the medium and low grade categories have difficulty in equating the denominator of fractions; (3) students with all three categories of high, medium, and low grades have difficulty in calculating fraction operations with three mixed numbers; and (4) students in the high, medium, and low grade
\end{abstract}


Errina Ida Zalima, Ferdianus Panggar Njanji, Lasmiatik, Leni Agustina, Maria Dela, Mika Ambarawati

Analisis Kesulitan Siswa Dalam Menyelesaikan Soal Cerita Operasi Hitung pada Bilangan Pecahan Campuran

categories have difficulty completing the mixed fraction counting operation.

Keywords: difficulty analysis, story problem, compute operations, mixed fraction numbers.

\section{PENDAHULUAN}

Pembelajaran matematika merupakan kegiatan yang dilakukan agar kegiatan lebih bermakna (Fuadi, Johar, \& Munzir, 2016). Pembelajaran matematika memiliki peranan penting dalam peningkatan kemampuan berpikir logis, rasional, kritis, cermat, efektif, dan efisien (Yusdiana \& Hidayat, 2018). Oleh sebab itu, siswa dalam memecahkan suatu masalah yang terkait dengan pembelalajaran matematika dituntut untuk menggunakan segala pengetahuan yang diperolehnya (Ambarawati, 2016).

Siswa dalam menyelesaikan masalah matematika terkadang mengalami kesulitan. Siswa sering mengalami kesulitan dalam memahami konsep dan operasi hitung. Selain itu, kesulitan belajar dapat terjadi dikarenakan faktor perilaku, akademis, dan atau kesehatan (Solek, 2015). Peran guru sangat penting dan dibutuhkan dalam mendiagnosis letak kesulitan belajar siswa saat memecahkan masalah (Ismail, 2016). Guru dapat menyiapkan asesmen dan analisis terhadap masalah belajar siswa, maka hasilnya dapat dijadikan informasi dalam meyusun program pembelajaran yang lebih efektif (Ghufron \& Risnawita, 2015).

Pemberian latihan soal cerita dapat digunakan untuk mengetahui kemampuan siswa menyelesaikan masalah matematika (Nurjanatin, dkk, 2017). Siswa dalam menyelesaian masalah soal cerita bukan hanya dituntut untuk memberikan jawaban namun juga menjelaskan langkah penyelesaiannya. Soal cerita merupakan bentuk evaluasi terhadap kemampuan konsep matematika yang dimiliki siswa (Wahyuddin, 2016). Penyelesaian soal cerita memaparkan bagaimana siswa mengidentifikasikan bagian yang diketahui, ditanyakan dan menjawab dengan operasi hitung yang tepat (Kaprinaputri, 2013).

Salah satu materi matematika sekolah dasar adalah pecahan campuran. Suwasi'ah (2019) mengatakan bahwa dalam praktik pembelajaran bilangan pecahan, sering ditemukan kendala yang menyebabkan capaian belajar kurang maksimal. Penguasaan konsep bilangan pecahan adalah hal yang sangat penting karena sebagai materi prasyarat dalam materi matematika maupun materi diluar matematika, bahkan menjadi salah satu materi pada tes angka dalam tes potensi akademik (Prafitriyani \& Dassa, 2016). 
Errina Ida Zalima, Ferdianus Panggar Njanji, Lasmiatik, Leni Agustina, Maria Dela, Mika Ambarawati

Analisis Kesulitan Siswa Dalam Menyelesaikan Soal Cerita Operasi Hitung pada Bilangan Pecahan Campuran

Pecahan campuran merupakan materi dalam matematika yang mulai diperkenalkan di sekolah dasar. Standar kompetensi dalam mempelajari pecahan campuran, yaitu menggunakan pecahan campuran dalam pemecahan masalah. Namun masih banyak siswa yang kesulitan dalam memahami materi pecahan. Kurangnya minat siswa dalam mempelajari operasi hitung pada pecahan biasanya ditunjukkan oleh kurangnya perhatian siswa terhadap proses pembelajaran materi pecahan (Badaruddin, Kadir, \& Anggo, 2016). Analisis mendalam diperlukan untuk mendeskripsikan jenis kesalahan dan alternatif penyelesaian untuk mengatasi kesulitan siswa dalam menyelesaikan soal cerita tentang pecahan. Oleh sebab itu, berdasarkan uraian di atas peneliti akan mendeskripsikan analisis kesulitan siswa dalam menyelesaikan soal cerita operasi hitung pada bilangan pecahan campuran.

\section{METODE PENELITIAN}

Jenis penelitian merupakan penelitian kualitatif deskriptif. Tujuan penelitian deskriptif adalah memberi gambaran dan klarifikasi mengenai sesuatu fenomena atau kenyataan sosial (Mulyadi, 2011). Metode kualitatif dianggap mampu menerangkan gejala atau fenomena secara lengkap dan menyeluruh (Rahmat, 2009). Subjek dari penelitian ini terdiri dari siswa kelas VI MI Darussalam Malang dengan kategori nilai tinggi, sedang, dan rendah. Instrumen yang digunakan adalah lembar tes soal cerita operasi bilangan pecahan campuran dan lembar wawancara. Data yang dianalisis adalah adalah hasil dari tes soal cerita operasi bilangan pecahan campuran dan wawancara. Teknik analisis data yang digunakan yaitu reduksi data, penyajian data, dan penarikan kesimpulan.

\section{HASIL DAN PEMBAHASAN}

Subjek penelitian ini adalah siswa kelas VI MI Darussalam Kota Malang. Berdasarkan hasil nilai tes soal cerita operasi hitung pada pecahan campuran dan kemampuan siswa dalam menyampaikan pendapat maka dipilih 3 siswa dengan kategori nilai tinggi, nilai sedang, dan nilai rendah. Tabel 1 menunjukkan nilai siswa dalam mengerjakan soal cerita berkaitan operasi hitung pada pecahan campuran sebagai berikut. 
Errina Ida Zalima, Ferdianus Panggar Njanji, Lasmiatik, Leni Agustina, Maria Dela, Mika Ambarawati

Analisis Kesulitan Siswa Dalam Menyelesaikan Soal Cerita Operasi Hitung pada Bilangan Pecahan Campuran

Tabel 1 Hasil Tes Soal Cerita Operasi Hitung Pada Pecahan Campuran

\begin{tabular}{ccccccc}
\hline \multirow{2}{*}{ No } & \multirow{2}{*}{ Siswa } & \multicolumn{4}{c}{ Penilaian } & \multirow{2}{*}{ Total skor } \\
\cline { 3 - 6 } & & $\mathbf{1}$ & $\mathbf{2}$ & $\mathbf{3}$ & $\mathbf{4}$ & \\
\hline 1 & Siswa 1 & 0 & 1 & 1 & 1 & 3 \\
\hline 2 & Siswa 2 & 1 & 1 & 0 & 0 & 2 \\
\hline 3 & Siswa 3 & 0 & 1 & 0 & 0 & 1 \\
\hline 4 & Siswa 4 & 0 & 0 & 0 & 0 & 0 \\
\hline 5 & Siswa 5 & 1 & 0 & 1 & 0 & 2 \\
\hline 6 & Siswa 6 & 1 & 1 & 1 & 1 & 3 \\
\hline 7 & Siswa 7 & 1 & 1 & 0 & 0 & 2 \\
\hline 8 & Siswa 8 & 1 & 1 & 1 & 1 & 4 \\
\hline 9 & Siswa 9 & 1 & 1 & 0 & 1 & 3 \\
\hline
\end{tabular}

Keterangan total dari penilaian adalah skor 0 jika siswa tidak menjawab soal, skor 1 jika siswa dapat menuliskan hal yang diketahui, ditanya, dan dijawab dari soal, skor 2 jika siswa Siswa dapat mengubah hal yang diketahui ke dalam bentuk matematika, skor 3 jika siswa dapat memaparkan jawaban dari soal dan skor 4 jika siswa dapat menyelesaikan jawaban dan menarik kesimpulan dari soal cerita operasi hitung pada pecahan campuran.

Berdasarkan kemampuan siswa dalam menyampaikan pendapat dan hasil tes soal cerita maka dipilih 3 siswa sebagai subjek penelitian. Subjek dengan kategori nilai tinggi adalah siswa 8 yang selanjutnya disebut subjek 1 . Subjek dengan nilai sedang adalah siswa 9 yang selanjutnya disebut subjek 2 , dan subjek dengan nilai rendah adalah siswa 4 yang selanjutnya disebut subjek 3.

Analisis kesulitan subjek pada jawaban tertulis dalam mengubah dari pecahan campuran ke pecahan biasa adalah sebagai berikut.

$$
\begin{aligned}
& \text { Jawab:3 } \frac{3}{2}+2 \frac{1}{4}-1 \frac{7}{8} \\
& =\frac{9}{2}+\frac{9}{4}=\frac{18}{6} \\
& =\frac{9}{4}-\frac{15}{9}=-6
\end{aligned}
$$

Gambar 1 Jawaban Subjek dalam Mengubah Pecahan Campuran ke Biasa

Subjek dalam mengubah dari pecahan campuran ke pecahan biasa mengalami kesulitan dalam operasi hitungnya. Umumnya, subjek menjawab 
Errina Ida Zalima, Ferdianus Panggar Njanji, Lasmiatik, Leni Agustina, Maria Dela, Mika Ambarawati

Analisis Kesulitan Siswa Dalam Menyelesaikan Soal Cerita Operasi Hitung pada Bilangan Pecahan Campuran

mengalikan bilangan asli dengan pecahan bagian pembilangnya. Hal ini juga didukung analisis hasil wawancara. Kutipan wawancara dengan subjek 3, dengan P sebagai peneliti dan S3 sebagai subjek 3.

$P \quad$ : Apakah kamu mengalami kesulitan saat mengerjakan ini?

S3 : Iya

$P \quad$ : Bagian mana yang belum dipahami?

S3 : Saya lupa cara mengubah ke pecahan biasa

Berdasarkan kutipan wawancara tersebut subjek belum mengetahui cara mengubah dari pecahan campuran ke pecahan biasa. Dengan demikian, ratarata siswa kelas VI di MI Darussalam Malang belum mampu menguasai dasar dari pecahan biasa sehingga menemukan banyak kesulitan dalam mengubah pecahan campuran ke pecahan biasa karena kurangnya pemahaman materi.

Penguasaan materi operasi penjumlahan dan pengurangan pada bilangan pecahan campuran merupakan hal yang paling penting dalam mengubah pecahan campuran ke pecahan biasa. Subjek dengan kategori nilai tinggi, sedang, dan rendah memiliki pemahaman konsep yang berbeda. Adapun subjek dengan kategori nilai rendah mengalami kesulitan dalam mengubah pecahan campuran ke pecahan biasa.

Analisis kesulitan subjek pada jawaban tertulis dalam menyamakan penyebut didasarkan pada jawaban tertulis subjek sebagai berikut.

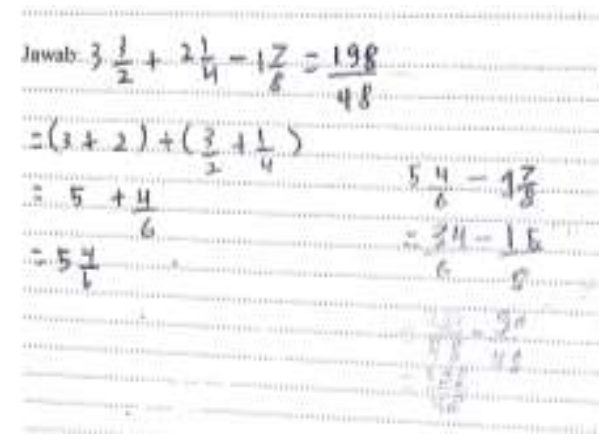

(a)

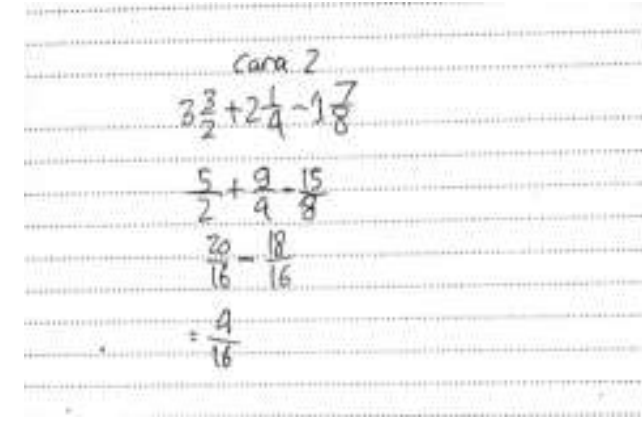

(b)

Gambar 2 Jawaban Subjek dalam Menyamakan Penyebut

Subjek masih belum mampu dalam menyamakan penyebut karena masih kurangnya pemahaman materi, beberapa subjek ada yang menebak jawabannya (gambar 2.a) dan ada yang menggunakan cara menyamakan penyebutnya dengan angka yang bisa dibagi semua bilangan pecahan tanpa menggunakan cara KPK atau mengalikan bagian-bagian penyebutnya. Akan tetapi, subjek tidak menyelesaikan dengan tepat, seperti salah satu jawaban tertulis siswa di bagian (gambar 2.b). Subjek mengalami kesulitan dalam 
Errina Ida Zalima, Ferdianus Panggar Njanji, Lasmiatik, Leni Agustina, Maria Dela, Mika Ambarawati

Analisis Kesulitan Siswa Dalam Menyelesaikan Soal Cerita Operasi Hitung pada Bilangan Pecahan Campuran

mengubah bentuk bilangan campuran ke bentuk bilangan pecahan biasa. Subjek juga mengalami kesulitan dalam menyamakan penyebutnya.

Hal ini juga didukung analisis hasil wawancara. Kutipan wawancara dengan subjek 2, dengan P sebagai peneliti dan S2 sebagai subjek 2.

$P \quad$ : Coba perhatikan jawabanmu dalam menyamakan penyebut

S2 : Hehehe... (tanpa ada jawaban)

$P \quad$ : Bagaimana cara menemukan angka 6?

S2 : Saya melihat jawaban teman saya

Berdasarkan kutipan wawancara tersebut subjek dengan nilai sedang mengalami kesulitan dalam menyamakan penyebut. Dengan demikian, kurangnya subjek dalam memahami materi mengakibatkan subjek kesulitan dalam menyamakan penyebut. Subjek dengan nilai tinggi dapat menyamakan penyebut. Akan tetapi, subjek dengan nilai sedang dan rendah mengalami kesulitan dalan menyamakan penyebut.

Analisis kesulitan subjek pada jawaban tertulis dalam operasi bilangan pecahan dengan tiga bilangan campuran adalah sebagai berikut.

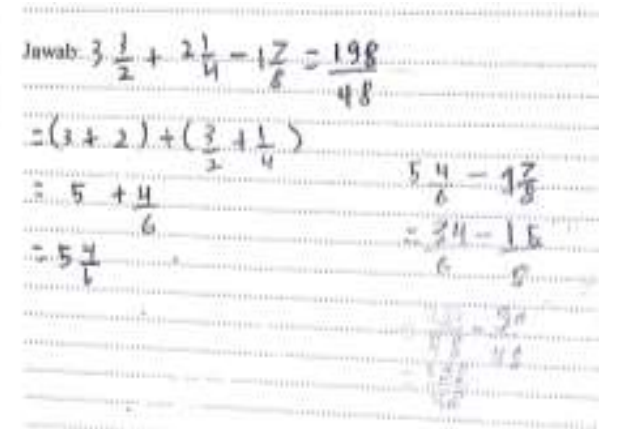

Gambar 3 Jawaban Subjek dalam Operasi Bilangan Pecahan

Jawaban subjek dalam menyelesaikan tiga bilangan pecahan campuran dalam satu penyelesaian menunjukkan adanya kesulitan. Jawaban tertulis subjek tidak efektif karena subjek mengoperasikan dua pecahan campuran dulu kemudian hasil operasi dari itu baru dioperasikan lagi dengan pecahan campuran yang terakhir. Selain itu, subjek mengalami kesalahan dalam menyamakan penyebut sebelum melakukan operasi hitung bilangan pecahan.

Hal ini juga didukung analisis hasil wawancara. Berikut kutipan wawancara dengan subjek 1 , dengan peneliti sebagai $P$ dan subjek 1 sebagai S1.
$P \quad$ : Bagaimana cara menyelesaikan soal cerita ini?
$S \quad$ :Dengan menggunakan cara 1
$P \quad$ : Tapi mengapa tidak dikerjakan sekaligus dengan cara 1?
$S \quad$ : Saya tidak tahu caranya 
Errina Ida Zalima, Ferdianus Panggar Njanji, Lasmiatik, Leni Agustina, Maria Dela, Mika Ambarawati

Analisis Kesulitan Siswa Dalam Menyelesaikan Soal Cerita Operasi Hitung pada Bilangan Pecahan Campuran

Berdasarkan kutipan wawancara tersebut subjek mengalami kesulitan dalam operasi hitung bilangan pecahan dengan tiga bilangan campuran. Subjek dengan ketiga kategori nilai tinggi, sedang, dan rendah mengalami kesulitan dalam operasi hitung bilangan pecahan dengan tiga bilangan campuran.

Analisis kesulitan subjek pada jawaban tertulis dalam menyelesaikan operasi hitung bilangan pecahan campuran sebagai berikut.

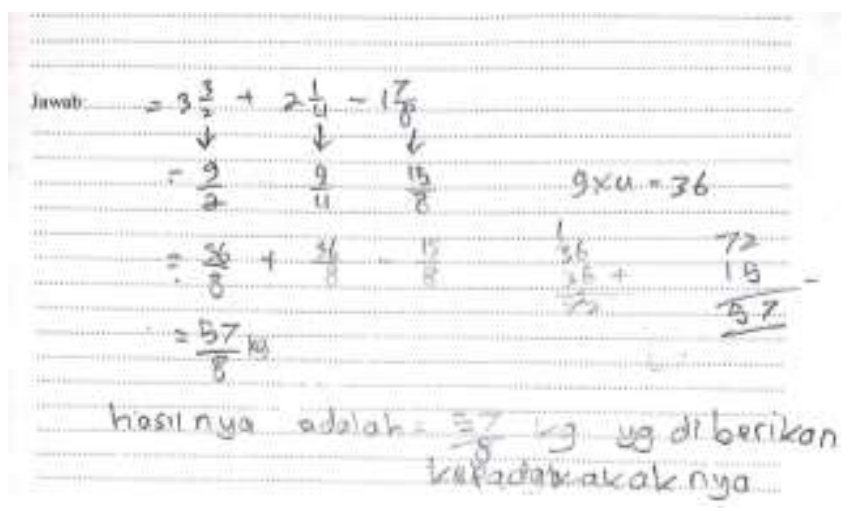

Gambar 4 Jawaban Subjek dalam Operasi Bilangan Pecahan Campuran

Berdasarkan jawaban tertulis subjek mengalami kesulitan dalam menyelesaikan operasi hitung bilangan campuran. Hal ini karena subjek kurang memahami konsep operasi hitung bilangan campuran.

Hal ini juga didukung analisis hasil wawancara. Kutipan wawancara dengan subjek 1, dengan peneliti sebagai P dan subjek 1 sebagai S1.

$P \quad$ : Coba perhatikan jawabanmu dalam menyamakan penyebut.

S1 : Itu saya salah dalam mengalikan

Berdasarkan jawaban tertulis dan hasil wawancara subjek mengalami kesulitan menyelesaikan operasi hitung bilangan pecahan campuran. Oleh sebab itu, penguasaan dasar pada operasi hitung bilangan pecahan campuran itu penting. Subjek dengan kategori nilai tinggi, sedang, dan rendah mengalami kesulitan dalam menyelesaikan operasi hitung bilangan pecahan campuran.

Pemahaman konsep dalam pembelajaran operasi hitung pecahan, guru harus dapat menggunakan model pembelajaran yang efektif dan menyenangkan. Hal ini sesuai dengan hasil penelitian (Mariani, 2015) menunjukkan bahwa mengajarkan konsep pecahan di sekolah dasar tidak hanya mentransfer konsep matematika, tetapi mengenai proses asal-usul, terjadinya dan pengembangan secara bertahap. Mengajarkan pecahan dimulai dengan menghubungkannya dengan kehidupan nyata, atau menempatkan dalam paradigma genesis kontekstual. Selain itu, pemahaman 
Errina Ida Zalima, Ferdianus Panggar Njanji, Lasmiatik, Leni Agustina, Maria Dela, Mika Ambarawati

Analisis Kesulitan Siswa Dalam Menyelesaikan Soal Cerita Operasi Hitung pada Bilangan Pecahan Campuran

konsep matematika perlu adanya penuntun yang konkret agar siswa mudah memahami masalah yang disajikan. Untuk mengatasi hal ini, dapat dibantu dengan menggunakan media gambar dan diperlukan strategi dari guru untuk memotivasi siswa agar aktif berdiskusi dan menyampaikan ide atau pendapat (Permadi \& Irawan, 2016). Ini juga didukung pendapat Indriani (2008) bahwa sebaiknya dalam proses pembelajaran guru menggunakan alat peraga untuk mempermudah siswa memahami konsep.

\section{KESIMPULAN DAN SARAN}

Kesimpulan dari penelitian ini adalah sebagai berikut. Siswa dengan kategori nilai tinggi, sedang, dan rendah memiliki pemahaman konsep yang berbeda. Siswa dengan kategori nilai tinggi dan sedang tidak mengalami kesulitan dalam mengubah pecahan campuran ke pecahan biasa. Akan tetapi, siswa dengan kategori nilai rendah mengalami kesulitan dalam mengubah pecahan campuran ke pecahan biasa.

Siswa dengan kategori nilai tinggi tidak mengalami kesulitan menyamakan penyebut. Akan tetapi, siswa dengan kategori nilai sedang dan rendah mengalami kesulitan dalam menyamakan penyebut bilangan pecahan. Siswa dengan ketiga kategori nilai tinggi, sedang, dan rendah mengalami kesulitan dalam operasi hitung bilangan pecahan dengan 3 bilangan campuran. Siswa dengan kategori nilai tinggi, sedang, dan rendah mengalami kesulitan dalam menyelesaikan operasi hitung bilangan pecahan campuran.

Adapun saran dari penelitian ini adalah sebagai berikut. Kesulitan dalam mengubah pecahan campuran ke pecahan biasa dapat dilakukan dengan menggunakan alat peraga dalam pembelajaran. Kesulitan dalam menyamakan penyebut bilangan pecahan dapat dilakukan dengan pemantapan dasar dan latihan soal dalam pembelajaran. Kesulitan dalam operasi hitung bilangan pecahan dengan 3 bilangan campuran dapat diatasi dengan menggunakan strategi pembelajaran yang efektif, inovatif, dan menyenangkan. Kesulitan dalam menyelesaikan operasi hitung bilangan pecahan campuran dapat dilakukan dengan melatih siswa berpikir cepat, teliti, dan kritis dengan model pembelajaran yang efektif dan efisien.

\section{DAFTAR RUJUKAN}

Ambarawati, M. (2016). Analisis Kemampuan Pemecahan Masalah Dalam Strategi Think Talk White. Jurnal Pedagogia, 5(2), 239-245.

Badaruddin, Kadir, \& Anggo, M. (2016). Analisis Kesalahan dalam Menyelesaikan Soal-Soal Operasi Hitung Pecahan Pada Siswa Kelas VII 
Errina Ida Zalima, Ferdianus Panggar Njanji, Lasmiatik, Leni Agustina, Maria Dela, Mika Ambarawati

Analisis Kesulitan Siswa Dalam Menyelesaikan Soal Cerita Operasi Hitung pada Bilangan Pecahan Campuran

SMP Negeri 10 Kendari. Jurnal Penelitian Pendidikan Matematika, 4(2), 43-56.

Fuadi, R., Johar, R., \& Munzir, S. (2016). Peningkatan Kemampuan Pemahaman dan Penalaran Matematis Melalui Pendekatan Kontekstual. Jurnal Didaktika Matematika, 3(1), 47-54.

Ghufron, M. N \& Risnawati, R. (2015). Kesulitan Belajar Pada Anak: Identifikasi Faktor Yang Berperan. Elementry, 3(2), 297-311.

Indriani, A. (2018). Penggunaan Blok Pecahan Pada Materi Pecahan Sekolah Dasar. Jurnal Ilmiah Pendidikan Matematika, 3(1), 11-16.

Ismail. (2016). Diagnosis Kesulitan Belajar Siswa dalam Pembelajaran Aktif Di Sekolah. Jurnal Edukasi, 2(1), 30-43.

Kaprinaputri, A. P. (2013). Kemampuan Menyelesaikan Soal Cerita Matematika. Jurnal Ilmiah VISI P2TK PAUD NI, 8(1), 10-15.

Mariani, S. (2015). Pengajaran Konsep Pecahan dan Kabataku Pecahan di Sekolah Dasar. Jurnal Matematika Integratif, 11(2), 120-129.

Mulyadi, M. (2011). Penelitian Kuantitatif dan Kualitatif Serta Pemikiran Dasar Menggabungkannya. Jurnal Studi Komunikasi dan Media, 15(1), 127-138.

Nurjanatin, I., Sugondo, G., \& Manurung, M. M. H. (2017). Analisis Kesalahan Peserta Didik Dalam Menyelesaikan Soal Cerita Pada Materi Luas Permukaan Balok Dikelas VIII-F Semester II SMP Negeri 2 Jayapura. Jurnal Ilmiah Matematika dan Pembelajarannya, 2(1), 22-31.

Prafitriyani, S \& Dassa, A. (2016). Exploration of Procedural Knowledge In Solving Arithmetic Operation In Fraction Of Grade XI Student At SMAN 17 In Makasar. Jurnal Daya Matematika, 4(2), 101-118.

Permadi, W. E \& Irawan, E. B. (2016). Memahami Konsep Pecahan Pada Siswa Kelas IV SDN Sumberejo 03 Kabupaten Malang. Jurnal Pendidikan, 1(9), 1735-1738.

Rahmat, P.S. (2009). Penelitian Kualitatif. Jurnal Equilibrium, 5(9), 1-8.

Solek, P. (2015). Mengenal Kesulitan Belajar dan Kesulitan Belajar Spesifik. Proseding Seminar Nasional PGSD UPY dengan Tema Strategi Mengatasi Kesulitan Belajar Ketika Murid Anda Seorang Disleksia. Hal 4-6.

Suwasi'ah. (2019). Meningkatkan Kemampuan Siswa dalam Menentukan Pecahan Senilai melalui Media Permainan Kartu Domino. Jurnal Prismatika, 2(1), 58-70.

Yusdiana, B. I \& Hidayat, W. (2018). Analisis Kemampuan Penalaran Matematis Siswa SMA Pada Materi Limit Fungsi. Jurnal Pembelajaran Matematika Inovatif, 1(3), 409-414.

Wahyuddin. (2016). Analisis Kemampuan Menyelesaikan Soal Cerita Matematika Ditinjau dari Kemampuan Verbal. Jurnal Tadris Matematika BETA, 9(2), 148-160. 